A. G. Titov, Z. R. Gil'vanova, E. A. Shevchenko,

M. K. Masnaviev, A. A. Bir

Ural Federal University

28 Mira Street, 620002, Ekaterinburg.

E-mail:paht@yandex.ru

\title{
Quantitative assessment of reentrainment in the electrocyclone*
}

The paper was devoted to the investigation of the reentrainment which was a parasitic effect incipient at the gas-cleaning systems - cyclones. It was demonstrated that the reentrainment arises at the speed of the aerosol from 14 to $27 \mathrm{~m} / \mathrm{sec}$. The quantitative characteristics of the reentrainment were determined.

Key words: the investigation of the reentrainment; cyclones; gas-cleaning systems; irrigation receiving electrode.

-The research project has been supported by Russian Foundation for Basic Research (grant 14-08-00046a).

〔C Titov A.G., Gil'vanova Z. R., Shevchenko E. A., Masnaviev M. K., Bir A. A., 2015

\section{Introduction}

The dust materials suppression at the chemical factories is the actual task [1]. The problem of the fine purification of the large gas volume from the disperse particles was existed. At present the applied multileaf lamellar electrostatic filters are too expensive, bulky and don't ensure the required high purification efficiency to $99.5-97 \%$. The wet gas cleaning at the emulsifiers troubles the utilization of the product since its release from the pulp and the following drying is requested. The large heat costs are necessary for this. Also the task of the elaboration of the high-performance equipment for the cleaning of the large gas volumes (hundred of thousands $\mathrm{m}^{3}$ /hour) with the receipt of the product in the dry form is actual [2].
The reentrainment by the dust collecting is the parasitic fact. It depends on the material dispersion, the gas stream speed, the electrode voltage, the design philosophy of the materials and other. The identification of the efficiency dependence of the work of the electrocyclones from mentioned factors represents the scientific and practical interest [3].

Early it was shown [4] experimentally that the gas purification efficiency decreases at the aerozol increasing speed above $15-17 \mathrm{~m} / \mathrm{sec}$ on the entrance to the electrocyclone. The centrifugal force is increasing at the increasing of the gas speed in the active zone that favors to the precipitation of the particles but at the constant length of the machine the time of the aerozol stay is decreasing, the effi- 
ciency of the charging of the particles is down, the ash Ola increases. It's result of that the particles don't have time to settle on the receiving electrode. The reentrain- ment is increasing because the already settled particles especially small knocked out of the sediment layer of large particles and turbulent eddies.

\section{Experiment part}

You want to exclude one of the factors to assess the degree of influence of the residence time of the gas flow in apparaten factor and the reentrainment on the decrease in the efficiency of particle collection in the electrocyclone. To exclude secondary reentrainment is necessary to irrigate the receiving electrode by film of water (wet mode). Then the particles that touched the water film will not be able to go back into the gas stream, and will be permanently removed from the active zone. Experiments were conducted in dry and wet mode of operation of the electrocyclone.

For research was used an laboratory experimental setup (stand), shown in fig. 1 . The stand included the electrocyclone 1 , palpatation 2, tranporter TNZh 3, the high voltage source (model IVNR-20-10) 4, a U-shaped tube to determine the hydraulic resistance of the electrocyclone 5 , the filter bag 6 , inlet pipe to the collector 7 , valves 8 , rotameters 9 , the pressure gauge 10 , the filter holder (type IRA-20-2) 11, the sampling tube 12 .

The test material was supplied by palpatation 2 in a disaggregated form on the inlet pipe 7 into the electrocyclone 1 . Caught ash was collected in the hopper of the electrocyclone 1 , and the purified air in the duct was removed through the bag filter 6 into the atmosphere.

For experiments with irrigation described above, the electrocyclone was supplemented with irrigation system and removal of the pulp (fig. 2).

For irrigation receiving electrode of the electrocyclone 1 used located in the cochlea of the irrigation system, consisting of a distribution of ring 2 and the feed tube 3 . The slurry from the hopper 4 is removed through the seal 5 in Montego 6 . The uniform irrigation of the wall at the translational-rotational motion of the gas was achieved when water flow was $81 / \mathrm{min}$.

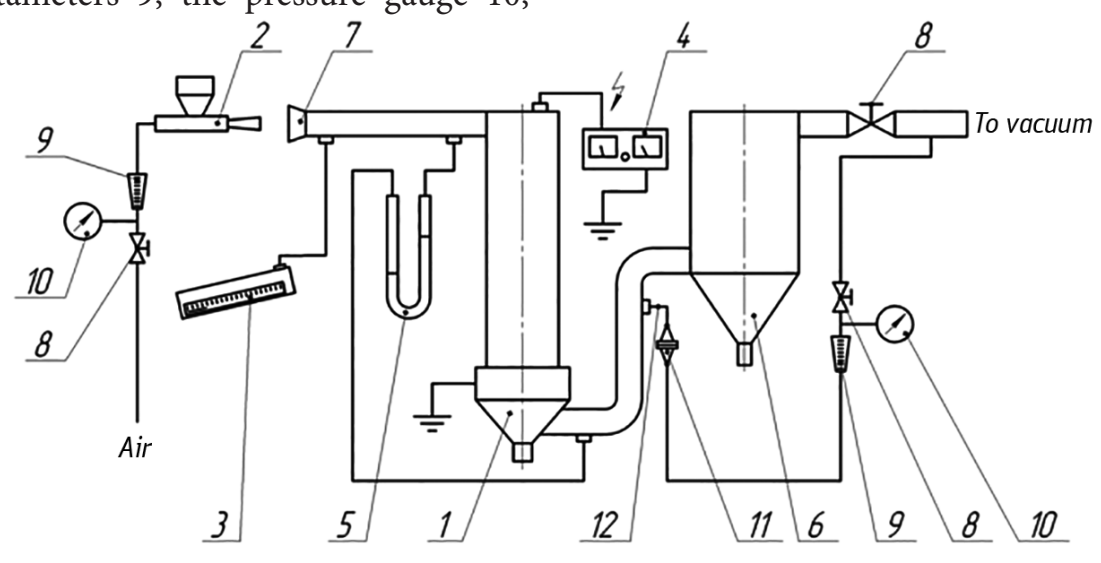

Fig. 1. Scheme of the experimental setup 


\section{Results and Discussion}

In the experiments on the capture of ash in the wet mode the reentrainment has been completely eliminated, however, the observed incomplete capture of ash, which can be explained by nagasarete particles and active turbulent mixing flow.

The amount of ablation can imagine $(1-n) \cdot 100 \%$ what allowed us to estimate the values of ablation in terms of purity. The dependence of entrainment speed at a fixed concentration of ash $16.5 \mathrm{~g} / \mathrm{m}^{3}$ are shown in fig. 3 .

From figure 3 it is seen that in wet mode at $U=17 \mathrm{kV}$ (electrocyclone mode) carryover is less than $1 \%$, lowering the voltage to $U=0 \mathrm{kV}$ (cyclone mode) ash reaches 5-7\%, whereas the ash in dry mode, when $U=17 \mathrm{kV}$ matter $12-25 \%$.

According to the experiment were also calculated values of the secondary ash as the difference between the degree of cleaning in wet and dry mode for corresponding points of the plan. The dependence of secondary reentrainment from the input speed and concentration of ash is shown in fig. 4.
From Fig. 4 shows that reentrainment varies in the interval from 5 to $35 \%$, the highest values are observed at gas velocities of more than $21 \mathrm{~m} / \mathrm{sec}$. The average value of the secondary ash is $10-15 \%$, which is significantly higher than the entrainment caused by necesarely. Thus, reentrainment reduces the efficiency of ash

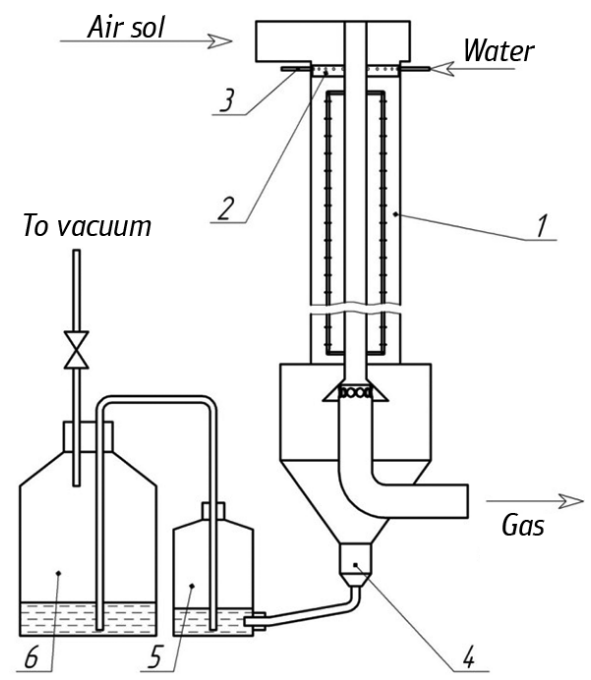

Fig. 2. Diagram of the cyclone to work in wet mode. Indicate in the figure: 1 - electro cyclone, 2 - distribution ring, 3 - feed tube, 4 - bunker, 5 - seal 6 - Montagu

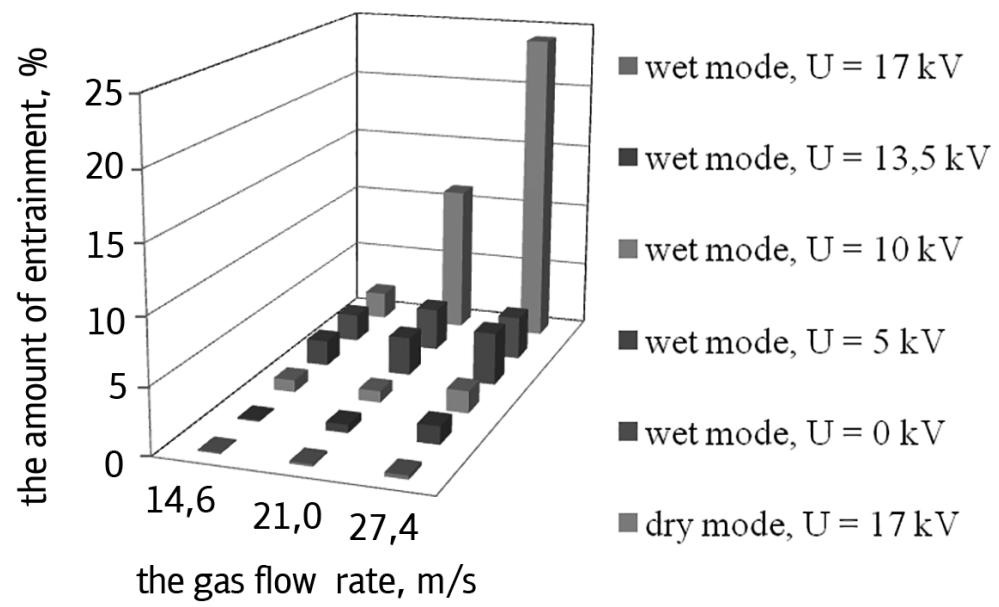

Fig. 3. The dependence of the amount of entrainment from the gas flow rate at different operating conditions of the electrocyclone 
in the electrocyclone at 5-35\% at velocities of aerosol 14.6-27.4 m/sec, respectively, by increasing the ablation is $10-50$ times.

\section{Conclusions}

The reentrainment is observed in the electrocyclone at a critical velocity of the aerosol at the inlet over $14-16 \mathrm{~m} / \mathrm{sec}$, which depends on the concentration and properties of the dust.

The reentrainment is almost completely eliminated by irrigation receiving electrode film of water. The degree of purification is above $95 \%$ without applying a voltage to the corona electrode and above $99 \%$ at a supply voltage of $17 \mathrm{kV}$ to the corona electrode.

Due to a secondary ablation of the degree of purification is reduced by $5-30 \%$.

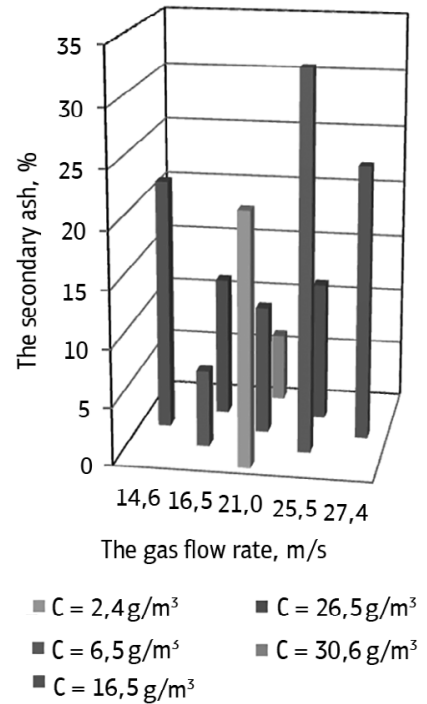

Fig. 4. The dependence of secondary ash at various initial concentrations of ash in the gas stream in the dry mode of operation of the cyclone from the gas flow rate at different operating conditions of the electrocyclone

1. Lim K. S., Kim H. S., Lee K. W. Comparative performances of conventional cyclones and a double cyclone with and without an electric field. J. of Aerosol Sciences. 2004, 35(1): 103-116. DOI: 10.1016/j.jaerosci.2003.07.001

2. Tsai R., Mills A. F. A model of particle re-entrainment in electrostatic precipitators. J. of Aerosol Science. 1995, 26(2): 227-239. DOI: 10.1016/0021-8502(94)00102-5.

3. Xiangrong Z., Lianze W., Keqin Z. A simple criterion for particle-wall adhesion in a wire-plate electrostatic precipitator. J. of Aerosol Sciences. 2005, 36(3): 411-417. DOI: 10.1016/j.jaerosci.2004.09.008

4. Titov A. G., Gilvvanova Z. R., Inyushkin N. V., Ermakov S. A., Shchelchkov I. P., Aitova A. I., Man'kov M. G., Tokareva N. A., Perfilov S. A. Efficiency of Electrostatic Cyclone Operation. Chemical and Petroleum Engineering. 2014, 49(9-10): 655-659. Doi:10.1007/s10556-014-9814-0. 


\author{
А. Г. Титов, 3. Р. Гильванова, \\ Е. А. Шевченко, М. К. Маснавиев, А. А. Бир \\ Уральский федеральный университет \\ 620002 Екатеринбург, ул. Мира, 28. \\ E-mail:paht@yandex.ru
}

\title{
Количественная оценка вторичного уноса в электроциклоне*
}

Статья посвящена исследованию вторичного уноса - паразитного явления, возникающего в газоочистных устройствах, - электроциклонах. Показано, что вторичный унос возникает при скоростях аэрозоля от 14 до 27 м/с. Определены количественные характеристики вторичного уноса.

Ключевые слова: исследование вторичного уноса, электроциклон, газоочистные устройства, орошение осадительного электрода.

*Исследование выполнено при финансовой поддержке РФФИ в рамках научного проекта № 14-08-00046a.

() Титов А. Г., Гильванова З. Р., Шевченко Е. А., Маснавиев М. К., Бир А. А., 2015

\section{Введение}

Улавливание пылевидных материалов на химических предприятиях является актуальной задачей [1]. Существует проблема тонкой очистки больших объемов газов от дисперсных частиц. Применяемые в настоящее время многопольные пластинчатые электрофильтры сравнительно дороги, громоздки и не обеспечивают требуемую высокую степень очистки 99,5-99,7 \%. Мокрая очистка газов в эмульгаторах затрудняет утилизацию продукта, т. к. требуется его выделение из пульпы и последующая сушка. Для этого требуются большие затраты тепла. Также актуальна задача разработки высокоэффективного оборудования для очистки больших объемов газов (сотни тыс. м³/ч) с получением продукта в сухом виде [2].

Вторичный унос при пылеулавливании - паразитное явление. Он зависит от дисперсности материала, скорости потока газа, напряжения на электродах, конструктивных особенностей аппаратов и др. Представляет научный и практический интерес выявление зависимости эффективности работы электроциклона от указанных факторов [3].

Ранее экспериментально было показано [4], что степень очистки газа снижается при увеличении скорости аэрозоля на входе в электроциклон свыше 15-17 м/с. При увеличении скорости газа в активной зоне возрастает 
центробежная сила, что благоприятствует осаждению частиц, но при постоянной длине аппарата время пребывания аэрозоля в активной зоне аппарата уменьшается, снижается эффективность зарядки частиц, увеличивается унос золы. Это является следствием того, что частицы не успевают осесть на осадительный электрод. Вторичный унос увеличивается, т. к. уже осевшие частицы, особенно мелкие, выбиваются из слоя осадка крупными частицами и турбулентными вихрями.

\section{Экспериментальная часть}

Чтобы оценить степень влияния времени пребывания газового потока в аппарате и вторичного уноса на снижение эффективности улавливания частиц в электроциклоне, требуется исключить один из факторов. Для исключения вторичного уноса необходимо орошать осадительный электрод пленкой воды (мокрый режим работы). Тогда частицы, коснувшиеся пленки воды, не смогут вернуться обратно в поток газа, а будут необратимо удаляться из активной зоны. Были проведены эксперименты в сухом и мокром режиме работы электроциклона.

Для проведения исследований была использована лабораторная экспери- ментальная установка (стенд), показанная на рис. 1.

Исследуемый материал пылеподатчиком 2 подавался в дезагрегированном виде по входной трубе 7 в электроциклон 1. Уловленная зола собиралась в бункере электроциклона 1 , а очищенный воздух по воздуховоду удалялся через рукавный фильтр 6 в атмосферу.

Для проведения опытов с орошением описанный выше электроциклон дополнялся системой орошения и удаления пульпы (рис. 2).

Для орошения осадительного электрода электроциклона 1 применялась расположенная в улитке ирригационная система, состоявшая из распре-

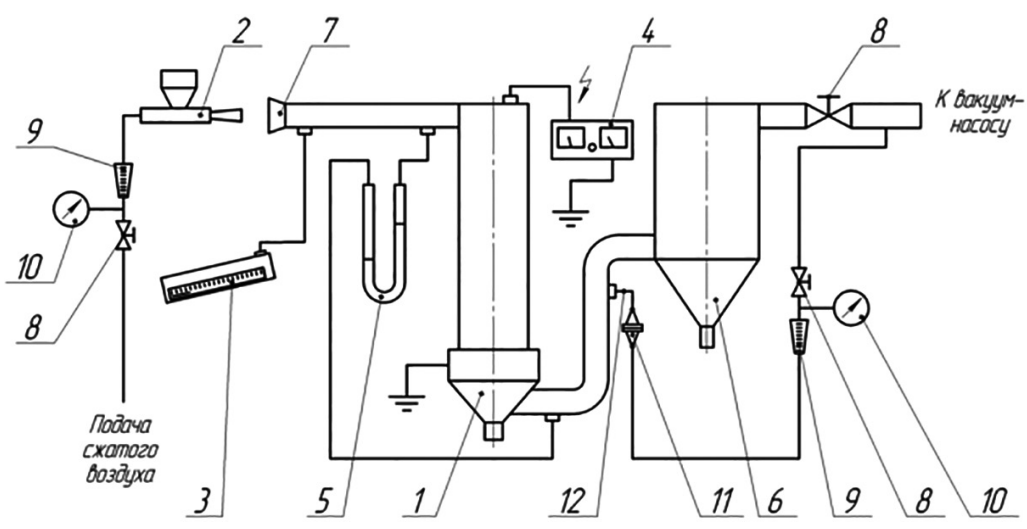

Рис. 1. Схема экспериментальной установки: электроциклон - 1, пылеподатчик - 2, тягонапоромер ТНЖ - 3, источник высокого напряжения (модель ИВНР-20-10) - 4, $\mathrm{U}$-образную трубку для определения гидравлического сопротивления электроциклона 5 , рукавный фильтр - 6, подводящую трубу с коллектором - 7, вентили - 8 , ротаметры 9, манометры - 10, фильтродержатель (типа ИРА-20-2) - 11, пробоотборную трубку - 12 
делительного кольца 2 и подающих трубок 3. Суспензия из бункера 4 удалялась через гидрозатвор 5 в монтежю 6. Равномерное орошение стенки при поступательно-вращательном движении газа достигалось при расходе воды 8 л/мин.

\section{Результаты и обсуждение}

В экспериментах по улавливанию золы в мокром режиме вторичный унос был полностью исключен, вместе с тем наблюдалось неполное улавливание золы, которое можно объяснить недозарядкой частиц и активным турбулентным перемешиванием потока.

Величину уноса можно представить как $(1-\eta) \cdot 100 \%$, что позволило оценить значения уноса в единицах степени очистки. Зависимость величины уноса от скорости при фиксированной концентрации золы 16,5 г/м ${ }^{3}$ показана на рис. 3.

На рис. 3 видно, что в мокром режиме при $U=17$ кВ (электроциклонный режим) унос составляет менее $1 \%$, при снижении напряжения до $U=0$ кB

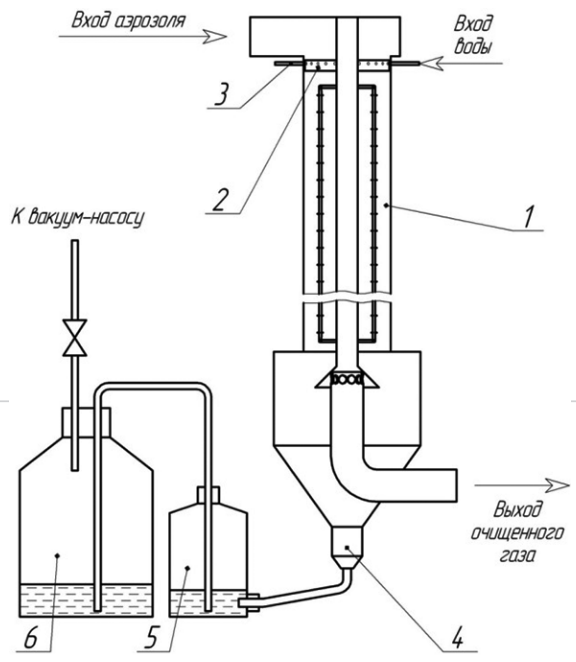

Рис. 2. Схема электроциклона для работы в мокром режиме: 1 - электроциклон,

2 - распределительное кольцо, 3 - подающие трубки, 4 - бункер, 5 - гидрозатвор, 6 - монтежю

(циклонный режим) унос достигает 5-7 \%, тогда как унос в сухом режиме при $U=17$ кВ имеет значения 12-25\%.

По данным эксперимента также были рассчитаны значения вторичного уноса как разница между степенью очистки в мокром и сухом режиме для

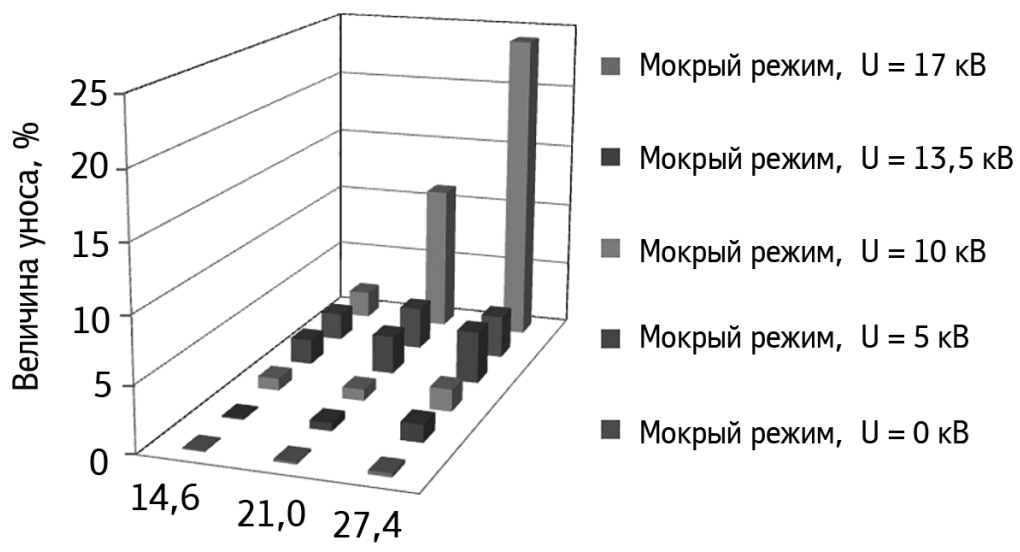

Скорость газового потока, м/с

Рис. 3. Зависимость величины уноса от скорости газового потока при различных режимах работы электроциклона 
соответствующих точек плана. Зависимость величины вторичного уноса от входной скорости и концентрации аэрозоля золы показана на рис. 4 .

На рис. 4 видно, что вторичный унос варьирует в интервале от 5 до 35 \%, наибольшие значения наблюдаются при скоростях газа более $21 \mathrm{~m} / \mathrm{c}$. Среднее значение вторичного уноса составляет 10-15\%, что существенно выше уноса, вызванного недозарядкой. Таким образом, вторичный унос снижает эффективность улавливания золы в электроциклоне на 5-35 \% при скоростях аэрозоля 14,6-27,4 м/с, соответственно увеличивая пылеунос в $10-50$ раз.

\section{Выводы}

Вторичный унос наблюдается в электроциклоне при критической скорости аэрозоля на входе свыше 1416 м/с, что зависит от концентрации и свойств пыли.

Вторичный унос практически полностью ликвидируется путем орошения осадительного электрода пленкой воды, степень очистки при этом выше 95 \% без подачи напряжения на коро-

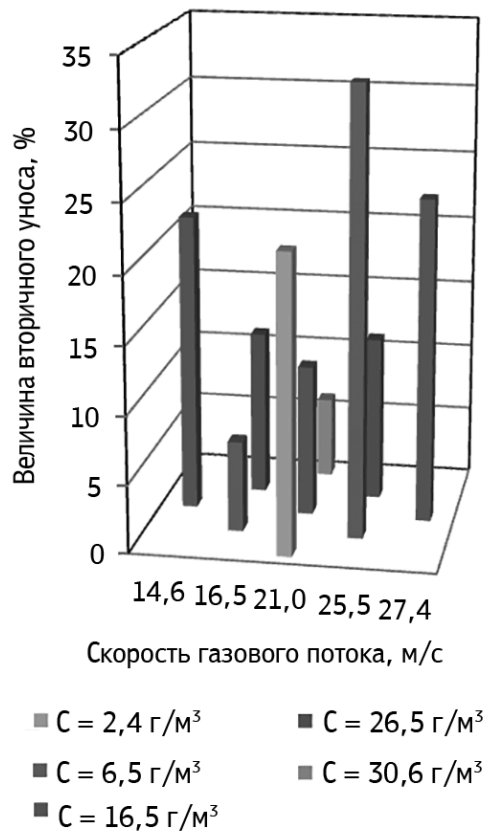

Рис. 4. Зависимость величины вторичного уноса от скорости газа при различных начальных концентрациях золы в потоке газа при сухом режиме работы электроциклона

нирующий электрод и выше 99 \% при подаче напряжения 17 кВ на коронирующий электрод.

Вследствие вторичного уноса степень очистки снижается на 5-30 \%.

1. Lim K. S., Kim H.S., Lee K. W. Comparative performances of conventional cyclones and a double cyclone with and without an electric field. J. of Aerosol Sciences. 2004, 35(1): 103-116. DOI: 10.1016/j.jaerosci.2003.07.001

2. Tsai R., Mills A. F. A model of particle re-entrainment in electrostatic precipitators. J. of Aerosol Science. 1995, 26(2): 227-239. DOI: 10.1016/0021-8502(94)00102-5.

3. Xiangrong Z., Lianze W., Keqin Z. A simple criterion for particle-wall adhesion in a wire-plate electrostatic precipitator. J. of Aerosol Sciences. 2005, 36(3): 411-417. DOI: 10.1016/j.jaerosci.2004.09.008.

4. Titov A. G., Gil'vanova Z. R., Inyushkin N. V., Ermakov S. A., Shchelchkov I. P., Aitova A. I., Man'kov M. G., Tokareva N. A., Perfilov S. A. Efficiency of Electrostatic Cyclone Operation. Chemical and Petroleum Engineering. 2014, 49(9-10): 655-659. DOI:10.1007/s10556-014-9814-0. 